Article

\title{
Linking Social Perception and Provision of Ecosystem Services in a Sprawling Urban Landscape: A Case Study of Multan, Pakistan
}

\author{
Syed Amir Manzoor ${ }^{1,2}, * \mathbb{B}$, Aisha Malik ${ }^{2}$, Muhammad Zubair ${ }^{2}$, Geoffrey Griffiths ${ }^{3}$ and \\ Martin Lukac 1,4 (D) \\ 1 School of Agriculture, Policy \& Development, University of Reading, RG6 6BZ Reading, UK; \\ m.lukac@reading.ac.uk \\ 2 Department of Forestry \& Range Management, FAS \& T, Bahauddin Zakariya University Multan, \\ 60000 Multan, Pakistan; aixha25@gmail.com (A.M.); zubair.fast@bzu.edu.pk (M.Z.) \\ 3 Department of Geography and Environmental Sciences, University of Reading, RG6 6AX Reading, UK; \\ g.h.griffiths@reading.ac.uk \\ 4 Faculty of Forestry and Wood Sciences, Czech University of Life Sciences Prague, \\ 16500 Prague, Czech Republic \\ * Correspondence: s.a.manzoor@pgr.reading.ac.uk or amir.kzd@gmail.com; Tel.: +44-777-492-8805
}

Received: 28 November 2018; Accepted: 23 January 2019; Published: 27 January 2019

\begin{abstract}
Urban sprawl causes changes in land use and a decline in many ecosystem services. Understanding the spatial patterns of sprawl and exploration of citizens' perception towards the sporadic urban expansion and its impacts on an ecosystem to deliver services can help to guide land use planning and the conservation of the urban ecosystem. Here, we spatially examined land use changes in Multan, Pakistan, and investigated public perception about urban sprawl and its impacts on the quality and provision of ecosystem services, using a survey instrument. The spatial analysis of the historical land cover of Multan indicated an exponential expansion of the city in the last decade. Large areas of natural vegetation and agricultural land were converted to urban settlements in the past two decades. The citizens of Multan believe that the quality and provision of ecosystem services have declined in the recent past and strongly correlate the deteriorating ecosystem services with urban sprawl. Education and income levels of the respondents are the strongest predictors of urban ecosystem health literacy. Citizens associated with laborious outdoor jobs are more sensitive to the changes in ecosystem services. We concluded that the rapidly expanding cities, especially in the tropical arid zones, need to be prioritized for an increase in vegetation cover, and economically vulnerable settlements in these cities should be emphasized in climate change mitigation campaigns.
\end{abstract}

Keywords: urban sprawl; ecosystem services; climate change; public perception; land use change; Multan

\section{Introduction}

The contemporary world is increasingly urbanizing [1]. The global urban population is projected to nearly double between 2000 and 2030 (from 2.84 billion to 4.9 billion); the bigger concern, however, could be that the extent of urban areas is expected to expand three-fold within the same period [2]. Consequently, an unlimited, sporadic, and unplanned expansion of urban areas into natural environment (farmlands, forests, wetlands, etc.) has been reported, a phenomenon called urban sprawl $[3,4]$. Urban sprawl is feared to draw on natural resources and degrade the quality and provision of ecosystem services [2]. As stressed upon in international agreements, such as the Convention on Biodiversity, understanding the ecological consequences of urban sprawl and 
integrating the management of ecosystem services into developmental plans is central to sustainable management of the urban ecosystem [3,5].

Sporadic expansion of urban settlements and its impacts on the urban ecosystem has been widely documented [6,7]. Urban sprawl can cause significant environmental changes as major ecosystem services, such as the provision of food and raw material, conservation of soil and natural vegetation, hydrology and climate, carbon sequestration, and landscape aesthetic, may degrade as a result of rapid expansion of urban areas $[1,4,5,8]$. Urban sprawl is central to the issues surrounding sustainable urban development as it generates multiple impacts, like increased air and water pollution, and loss of local biodiversity and open areas with consequent detrimental effects on human health $[9,10]$.

Several approaches have been proposed to assess the effects of unplanned urban expansion on environmental capital and to incorporate these assessments into urban management plans. For example, boundaries for projected future urban expansion have been assessed by gauging Environmental Carrying Capacity (ECC) of a landscape. ECC—often measured by indicators, such as ecological footprint and biocapacity [6,11] —verifies whether a given developmental plan is consistent with certain environmental targets, thus helping to devise environmentally-sustainable spatial plans for future urban development [12,13]. Ecosystem Services Bundles (ESB) is another concept proposed for identifying trade-offs and synergies between different ecosystem services based on the socio-cultural preferences of the stakeholders $[14,15]$. This approach has been used to identify areas in a landscape where human-environment interaction produces desirable or undesirable ecosystem services $[15,16]$. Recently, more multi-disciplinary indicators, such as Technomass [17] and Benefits Relevant Indicators (BRI) [18], have been proposed to link biophysical and social science approaches for measuring urban ecosystem services.

The growing concern about urban sprawl has led to policy formulation at a large scale [19-21]. Public concern about sprawl and its impacts on the provision of ecosystem services is germane to policymakers as the level of public concern is likely to affect the political and social acceptance of programs and policies [22]. Evidence suggests that the exploration of public perception and opinion offers opportunities to incorporate citizen awareness and needs that are traditionally missing in urban management [23]. Ecosystem services are often assessed through economic or biophysical indicators [24]; few attempts have been made to address the perspective of citizens' perception towards the evaluation of an ecosystem to deliver services [25]. Social evaluations help to understand the motivations behind preferences and opinions towards a problem, thus unveiling values that may otherwise remain unexplored by economic or biophysical assessment [26]. In this context, survey instruments have been successfully used to investigate indicators of public perception about the social and environmental impacts of urban sprawl [20]. A number of such surveys, like referenda, ballot measures, and polls, suggest that public concern about the environmental impacts of sporadic urban expansion has grown in recent years [22]. Socio-demographic factors, such as literacy [27], gender [28], age group [29], professional affiliation [30], and financial stability [31] of the citizens often shape public opinion about rapid urban expansion and associated social and environmental problems.

At the global scale, developing countries are hotspots of rapid urban expansion; 15 of the world's 20 most populous cities exist in these countries [32]. Although the consequences of urban sprawl are frequently reported in the developed countries [8,20,33,34], analyses of urban sprawl in developing countries, especially in Pakistan, remain scant. In Pakistan, the annual growth rate of urban population is nearly 2.5 percent, one of the fastest in South Asia [35]. Baseline studies are, therefore, needed to map the rapidly expanding urban landscape of the major cities in the country and to make a qualitative assessment of the socio-demographic factors that shape public opinion of urban sprawl and its impacts on the urban environment. A handful of studies on the urban expansion of some cities in the central and northern parts of Punjab province have recently been reported [31,36], however-to the best of our knowledge - there has been no study carried out in the southern parts of Punjab province, which is a speedily developing region of Pakistan. This study, therefore, adds to the literature by exploring 
the spatial, as well as social, dimensions of urban sprawl and their impacts on ecosystem services in southern Punjab, Pakistan. Specifically, three questions led our analysis:

1. To what extent does the public in the study area believe the quality and provision of ecosystem services has changed in the recent past (i.e., the past ten years)?

2. Having answered the first question, to what extent does the public believe that urban sprawl is responsible for the perceived changes in the quality and provision of ecosystem services?

3. What are the underlying socio-demographic causes for these individual opinions?

Additionally, we used GIS tools to visualize and quantify historical land use changes. In the last section, we discuss the implications of the findings for the sustainable urban management of the study area.

\section{Methodology}

This study comprised two methodological steps. In the first step, we quantified historical land use changes in the study area to identify the extent and patterns of rapid urban expansion and transitions between different land use classes. The second step comprised a survey study that investigated the perception of the local community about the changes in ecosystem services because of sporadic urban expansion in Multan.

\subsection{Study Area}

The main area for this study is the urban center of District Multan, i.e., Multan city. We chose this area primarily for two reasons: (1) Multan is one of the fastest expanding cities in Pakistan [32], yet there are no prior studies on the spatiotemporal changes in the landscape of the Multan region, and (2) Multan is located in the southern parts of Punjab province, which is reportedly amongst the most vulnerable parts of Pakistan to climate change [37,38]. The region has been in the spotlight in recent years because of extreme climate change events [39]. To generate a broader picture of land use change, we initially included District Lodhran and District Khanewal, the two adjoining administrative units of Multan (Figure 1), in the spatial analysis. Then, we restricted the survey to the city of Multan. The District Multan, which comprises Multan city, is one of the largest administrative units in Pakistan; it currently covers an area of $3720 \mathrm{~km}^{2}$ and has a population of nearly 3.1 million, $42 \%$ of which live in Multan city [40].

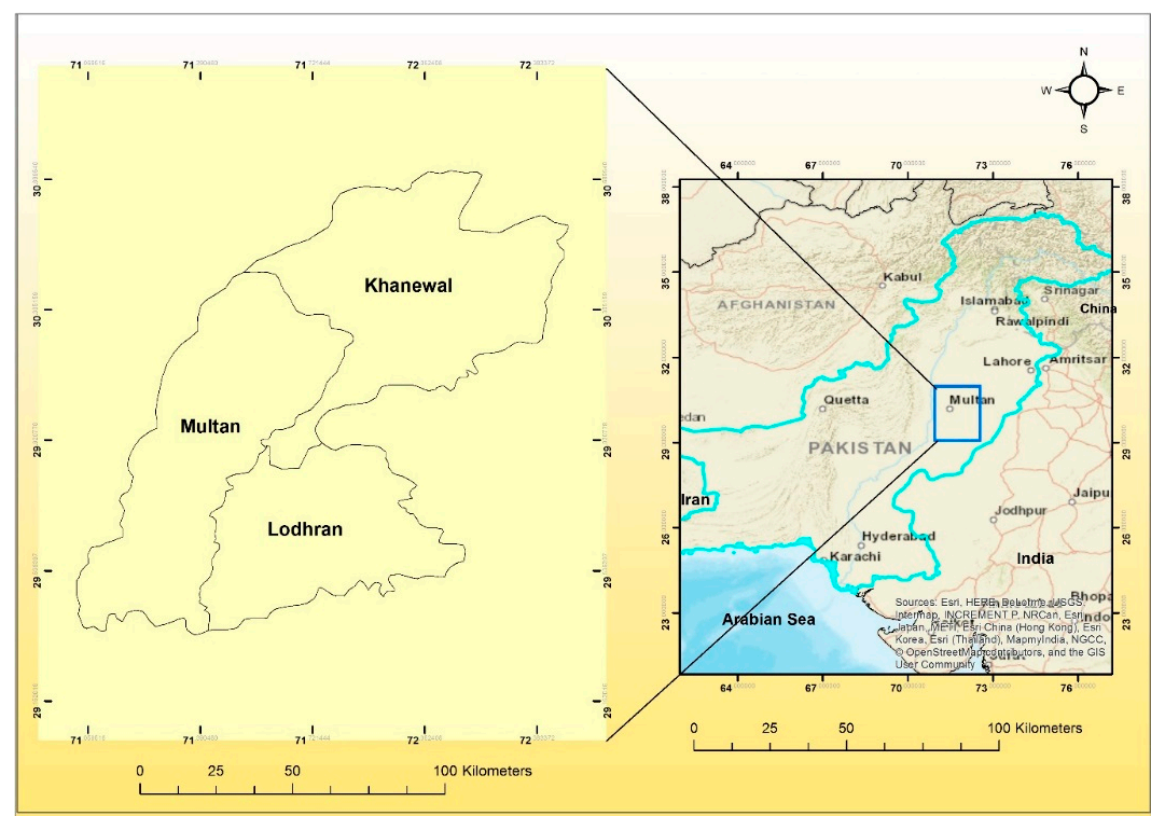

Figure 1. The case study site (District Multan and adjoining Districts of Khanewal and Lodhran). Geographic Coordinate System: GCS_WGS_1984, Datum: D_WGS_1984. 
Step 1: Quantifying the Historic Land Use Change Patterns in Multan City

To quantify the historical land use changes, we downloaded land cover maps for the years 1992, 2002, and 2015 from "The European Space Agency CCI" global land cover product (www.esalandcovercci.org). These global land cover maps, at a spatial resolution of $300 \mathrm{~m}$, were masked to the extent of the study area using ESRI ArcGIS 10.6. As per the "The European Space Agency CCI" global land cover product symbology, the study area covered 21 different land cover types. For ease of analysis, we combined similar land cover classes (Supplementary Table S1) to produce five major land cover types: Arable land, Vegetation cover (tree/shrub), Urban area, Bare area, and Body of water. The area under each of these five land cover classes was computed for the year 1992, 2002, and 2015 , followed by a comparative analysis of the land cover change during 1992-2002 and 2002-2015. Quantitative analysis of the change in the urban areas and the rest of the land cover classes was carried out following recommended protocols [41,42]. Furthermore, we used the land change modeler tool in TerrSet Geospatial Monitoring and Modelling Software to produce maps for the spatial trend of change. These maps helped to decipher the patterns and dimensions of land use transitions. The maps for spatial trends of change generalized the pattern of change by assigning a value of 0 to the areas of no change and a value of 1 to the areas of change.

Step 2: Perception of the Local Community about the Changes in Ecosystem Services as Affected by Urban Sprawl

After generating visual maps of historical urban expansion in the study area, we designed a survey instrument to query the perception of the local community of Multan city about the changes in ecosystem services as a consequence of urban sprawl in the last decade.

\subsection{Design of the Survey Instrument}

The survey was conducted in Multan following published protocols [43,44]. The survey consisted of 14 questions, the range of responses to all of which corresponded to the 5-point Likert scale from 1 (strongly disagree) to 5 (strongly agree). These 14 questions were divided into two constructs of seven questions each (Table 1). Both constructs represent a theory-based concept [45]. The first construct comprised the questions about the perception of the respondents towards the changes in ecosystem services in Multan city in the last decade. The second construct was computed from the questions that determined the extent to which the respondents believed the observed changes in the ecosystem services were caused due to the sprawl of Multan city. Both the constructs were measured for internal consistency with Cronbach's alpha using Statistical Package for Social Scientists (SPSS) version 21.0 [46]. The explanatory variables in this study included gender (male/female), age group (youth/mature), profession (farming/other than farming), literacy (illiterate/literate), and the area of residence (urban/peri-urban) of the respondents. These variables were chosen after a detailed review of the published literature $[27,28,31,47]$. A detailed analysis of the explanatory variables is presented in Table 2. 
Table 1. Constructs designed in the survey instrument.

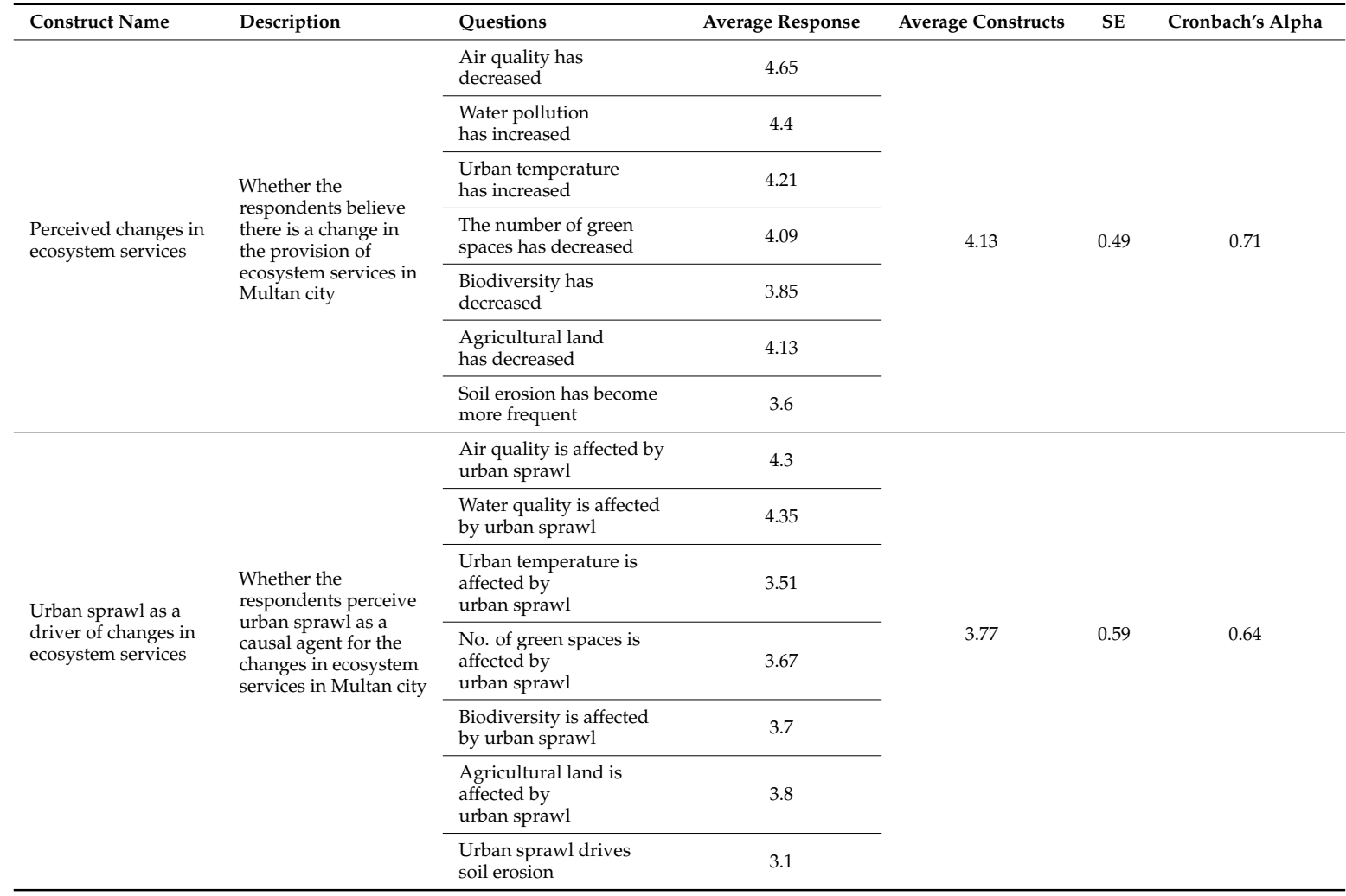

Table 2. Explanatory variables/demographic profile of the respondents.

\begin{tabular}{|c|c|c|c|}
\hline & Demographic Characteristics $(n=148)$ & Frequency & Percent \\
\hline \multirow{2}{*}{ Gender } & Male & 137 & 57.8 \\
\hline & Female & 100 & 42.2 \\
\hline \multirow{2}{*}{ Age } & Youth (18-35 years) & 156 & 65.8 \\
\hline & Mature (>35 years) & 81 & 34.2 \\
\hline \multirow{2}{*}{ Literacy } & Illiterate & 83 & 35 \\
\hline & Literate & 154 & 65 \\
\hline \multirow{2}{*}{ Profession } & Farming & 61 & 25.7 \\
\hline & Others & 176 & 74.3 \\
\hline \multirow{2}{*}{ Residential area } & Urban & 152 & 64.1 \\
\hline & Peri-Urban & 85 & 35.9 \\
\hline \multirow{2}{*}{ Monthly Income } & Low Income Class $<\$ 250$ & 73 & 30.8 \\
\hline & High Income & 164 & 69.2 \\
\hline
\end{tabular}

\subsection{Population Sampling}

We used a stratified random sampling method for this survey study. We targeted the survey towards the urban and peri-urban areas of Multan, and within the urban and peri-urban areas, we randomly surveyed citizens belonging to different professions, categories of literacy, age groups, gender, and monthly income. The sample size for the survey was determined by the total population of Multan city (1.8 million), using the sample size calculation formula proposed by Yamane [48]. We set the confidence interval at $10 \%$ and used a $95 \%$ confidence level. With these parameters, the sample 
size derived was 100 . We, however, recorded the responses of 237 respondents for this study. A map showing the spatial distribution of the respondents is shown in Supplementary Figure S1.

\subsection{Statistical Analysis}

The data obtained from the questionnaire were coded and entered into SPSS version 21.0 for descriptive and inferential statistics. We ran a multiple regression model to assess the factors affecting the perception of the residents of Multan about the changes in the ecosystem services of the city and the extent to which people hold urban sprawl responsible for these changes.

\section{Results}

Land use maps of the study area at three points in time, the year 1992, 2002, and 2015 are shown in Figure 2. Spatial analysis of these land use maps suggests that, in 1992, the urban area covered 1800 ha in Multan, which increased by $112.5 \%$, extending to 3825.9 ha by 2002 . A little over a decade later, in 2015, an exponential urban expansion occurred as the urban area reached 22,998.9 ha, which is a staggering $501.1 \%$ increase from the year 2002. Figure 3 shows an enlarged view of the area that experienced most of the urban sprawl. Among the other land use types, the arable land saw a reduction of $0.15 \%$ from $1992-2002$ and a further decline of $1.59 \%$ by 2015 . The vegetation cover declined, too; there was a reduction of 3.2\% from 1992-2002, and by 2015, 7.4\% of the remaining vegetation cover had disappeared. A quantitative analysis of the land use change is given in Table 3.

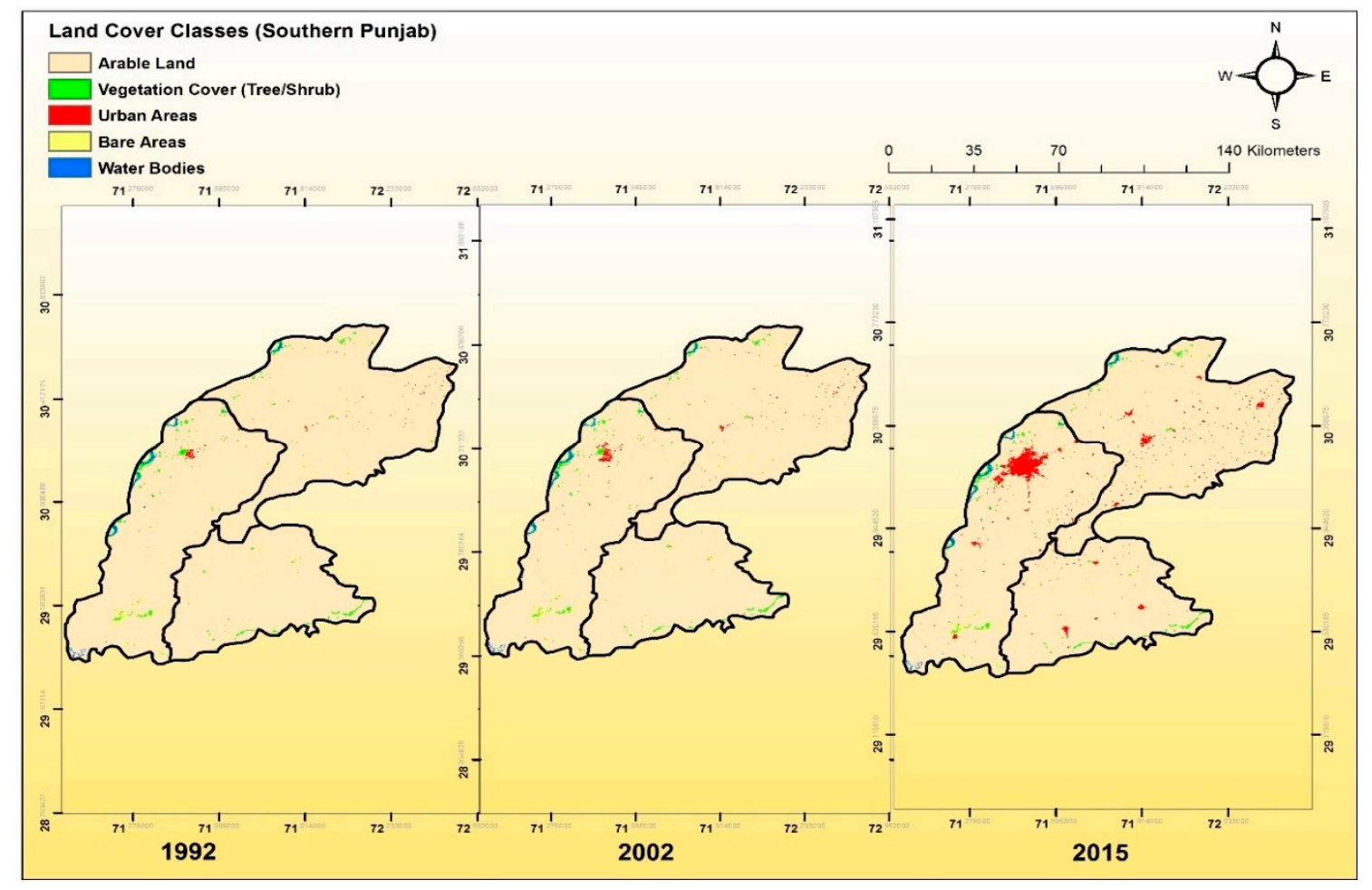

Figure 2. Spatiotemporal changes in the land use patterns of Multan city and adjoining areas (Khanewal and Lodhran) from the year 1992 to 2002 and 2015. 


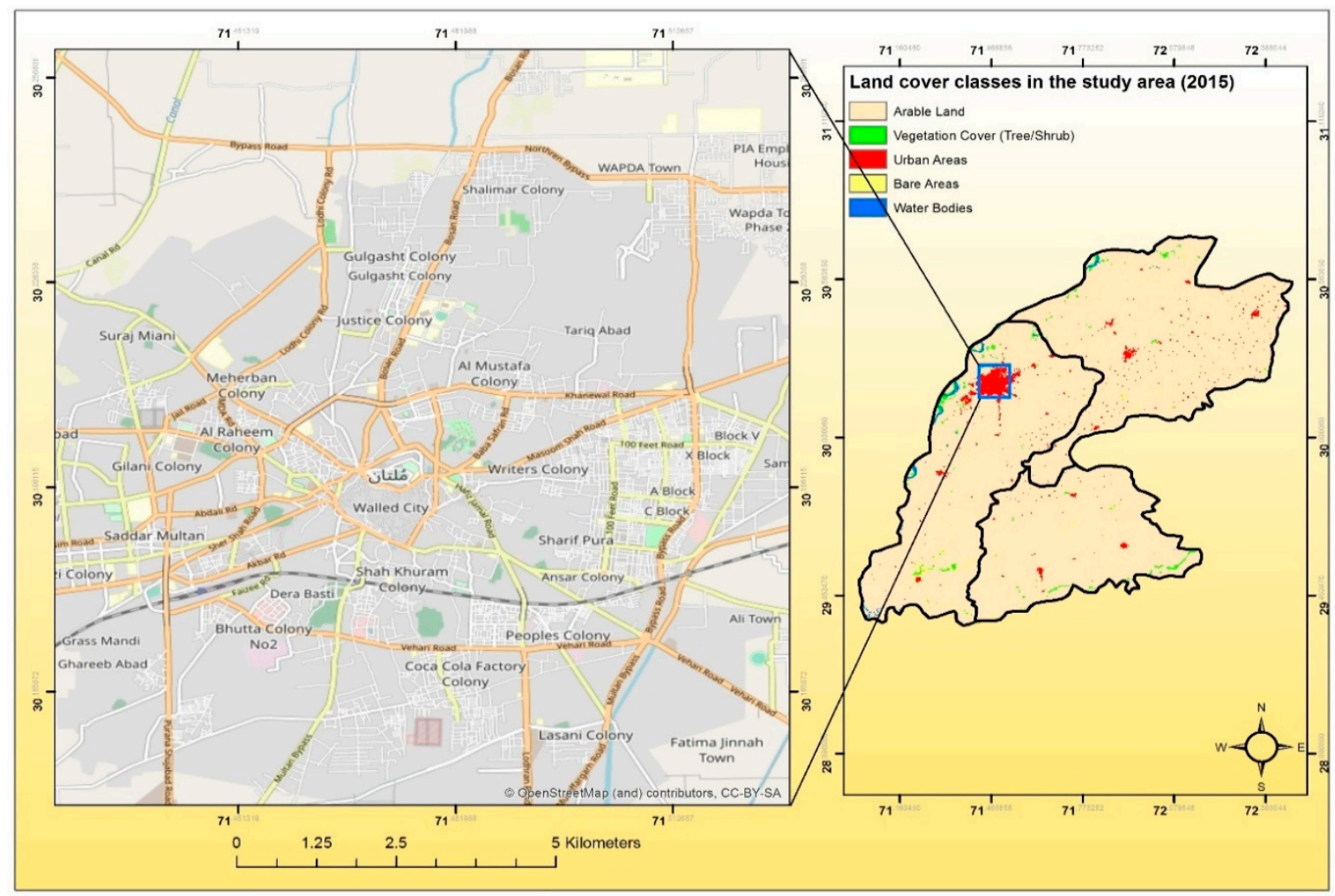

Figure 3. An enlarged view of the study area showing the site that experienced most of the urban sprawl.

Table 3. In selected cities of Southern Punjab (Multan, Khanewal, and Lodhran) area under different land cover classes (hectares) and change in the land use classes (1992, 2002, and 2015).

\begin{tabular}{cccccccc}
\hline \multirow{2}{*}{ Land Cover Class } & \multirow{2}{*}{$\mathbf{1 9 9 2}$} & \multirow{2}{*}{$\mathbf{2 0 0 2}$} & $\mathbf{2 0 1 5}$ & Change (\%) & Change (\%) & Change (ha) & Change (ha) \\
\cline { 3 - 8 } & & & & $\mathbf{1 9 9 2 - 2 0 0 2}$ & $\mathbf{2 0 0 2 - 2 0 1 5}$ & $\mathbf{1 9 9 2 - 2 0 0 2}$ & $\mathbf{2 0 0 2 - 2 0 1 5}$ \\
\hline Arable land & $1,123,652.20$ & $1,121,903.70$ & $1,103,968.40$ & -0.16 & -1.6 & -1748.5 & -17935.3 \\
Vegetation cover & $12,845.40$ & $12,438.60$ & $11,529.70$ & -3.2 & -7.4 & -406.8 & -908.9 \\
Urban area & 1800.4 & 3825.9 & $22,998.90$ & 112.5 & 501.1 & 2025.5 & 19173 \\
Bare area & 7158.5 & 7054.6 & 6959.4 & -1.5 & -1.3 & -103.9 & -95.2 \\
Body of water & 4933.9 & 5167.6 & 4933.9 & 4.8 & -4.5 & 233.7 \\
\hline
\end{tabular}

The preliminary spatial analysis (Table 3) indicated that urban area, arable land, and vegetation cover (tree/shrub) experienced most of the land use transition between 1992-2015. Further analysis revealed that the largest contribution to the net change in arable land and vegetation cover (tree/shrub) was that of urban area. Nearly 18,000 ha of arable land and 800 ha of vegetation cover (tree/shrub) that existed in 2002 was urbanized by 2015. Moreover, almost 150 ha of vegetation cover (tree/shrub) changed to arable land between 2002-2015. Detailed analysis of the contributions to the net change in these land use classes is presented in Supplementary Figure S2, while visual maps showing a spatial gain/loss in these land use classes are presented in Supplementary Figure S3. We also produced maps of the spatial trend of change which indicated that most of the conversion from arable land and vegetation cover (tree/shrub) was concentrated in the western parts of the study area (Figure 4). 


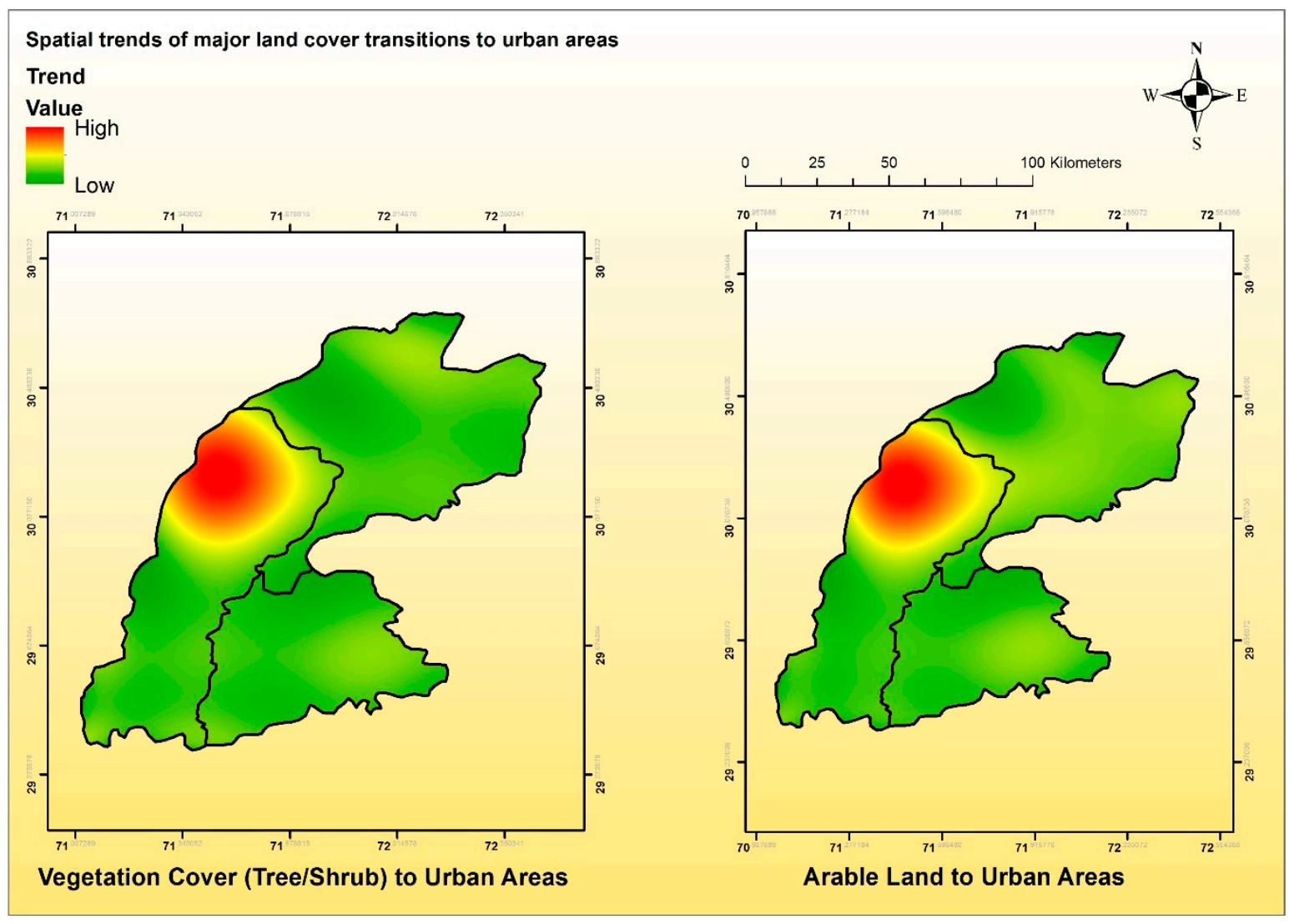

Figure 4. Maps of spatial trends of change from other land use classes to urban areas.

3.1. Understanding Public Perception of Urban Sprawl and Its Effects on the Provision of Ecosystem Services through Qualitative Analysis

\subsubsection{The Demographic Profile of the Respondents}

We received 237 usable responses from the respondents living in the central urban and peri-urban areas of Multan city. Demographic data of the survey respondents are presented in Table 2.

\subsubsection{Constructs}

Descriptive statistics for the two constructs created from the questions in the survey administered to the citizens of Multan $(n=237)$ are presented in Table 1 . Scale for all constructs was 1 to 5 , from strongly disagree (1) to strongly agree (5). The two constructs formed the two dependent variables of the study; the first construct/variable aimed to determine the perception of the citizens about the changes in the ecosystem services in the last decade, and the second construct formed a variable that gauged the extent to which the citizens believed that the observed changes in the ecosystem services are due to the urban sprawl. Both the constructs showed a dependable value of reliability test (Cronbach's alpha of 0.72 and 0.64 ), indicating a good degree of internal consistency.

\subsubsection{Multiple Regression Model}

The details of the multiple regression model parameters are shown in Table 4. In the first model, where we regressed the perception of the citizens about the change in ecosystem services in Multan against a range of independent variables, the model output suggested that our dependent variable was significantly affected by the levels of literacy and monthly income. When compared to the literate respondents, the illiterate citizens showed a significantly higher sensitivity towards the deteriorating ecosystem services in the Multan region $(\beta=-0.234)$. Similarly, the respondents in the low-income 
category showed more awareness of this issue as compared to the high-income category respondents $(\beta=-0.167)$.

Table 4. Multiple regression analysis results showing relationships between dependent and independent variables. Constructs were created from questions in a survey administered to the citizens of Multan $(n=237)$.

\begin{tabular}{|c|c|c|c|c|c|c|}
\hline & Dependent Variables & $\begin{array}{l}\text { Independent } \\
\text { Variables }\end{array}$ & $\begin{array}{c}\text { Unstandardized } \\
\text { Regression Coefficient }\end{array}$ & $\begin{array}{c}\text { Standardized } \\
\text { Coefficient (Beta) }\end{array}$ & $p$-Value & $\mathbf{R}^{2}$ \\
\hline \multirow{3}{*}{ Model 1} & \multirow{3}{*}{$\begin{array}{l}\text { Perception about changes } \\
\text { in ecosystem services } \\
\text { in Multan }\end{array}$} & Gender & 0.032 & 0.31 & 0.627 & \multirow{3}{*}{14.5} \\
\hline & & Literacy & -0.234 & -0.22 & $0.001 *$ & \\
\hline & & Profession & 0.094 & 0.081 & 0.243 & \\
\hline \multirow{4}{*}{ Model 2} & \multirow{4}{*}{$\begin{array}{l}\text { Perception about urban } \\
\text { sprawl as a driver of } \\
\text { change in the ecosystem } \\
\text { services in Multan }\end{array}$} & Gender & -0.031 & -0.025 & 0.697 & \multirow{4}{*}{13.2} \\
\hline & & Age & -0.020 & -0.015 & 0.807 & \\
\hline & & Literacy & -0.354 & -0.275 & $0.001 *$ & \\
\hline & & Profession & -0.178 & -0.126 & 0.064 & \\
\hline
\end{tabular}

In the second model where, against the same set of independent variables, we regressed a construct computed from the questions on the extent to which the citizens believed the perceived or observed changes in the ecosystem services are due to urban sprawl, literacy was a significantly important determinant. We found that illiterate respondents $(\beta=-0.354)$ strongly believed that urban sprawl is the driving factor behind the declining ecosystem services in the Multan region. Detailed analysis of how responses within each demographic category varied is shown in the Supplementary Figures S4 and S5.

\section{Discussion}

Anthropogenic activities are the drivers of major changes in the modern world; the impact of rapidly expanding cities on environmental resources and ecosystem services is a notable example [49,50]. In the recent past, urban encroachment of natural ecosystems have increased exponentially and are expected to continue doing so; almost 60 percent of all the urban settlements that will exist by 2030 are forecast to be built during 2000 and 2030 [51]. The situation is even graver in developing countries where there is more of an urban sprawl than planned urban expansion [52]. This sprawl can be attributed to several drivers: Mounting population pressure, increase in human mobility, finding houses in relatively low-price areas, and search for livelihood opportunities, to name a few [53].

Rapid urban expansion is often seen as an indicator of economic development [54]; at the same time, it affects the environmental resources and provision of ecosystem services [55]. These effects may include a decrease in agricultural land, loss of biodiversity, increased greenhouse gases emissions, urban heat island effect, increase in municipal costs, spatial segregation of natural habitats, and noise, light, soil, and water pollution [7,56,57]. There is now a global interest to restore ecosystem services in urban areas, given international commitments, such as Convention on Global Biodiversity, for the restoration of at least 15 percent of degraded ecosystems by 2020 [58]. These also conform to United Nation's agenda on a green economy for the 21st century, as well as Sustainable Development Goals.

In this study, we analyzed the patterns of historical urban expansion in Multan, Pakistan, and investigated the perception of the local community about the changes in ecosystem services as affected by the urban sprawl. The GIS-based analysis of the land cover changes in Multan suggested that the urban areas speedily increased, especially in the last 15 years or so, resulting in a decline in the 
vegetative cover in the region. In an earlier study conducted in Islamabad, the capital of Pakistan, key changes in land use and land cover, such as an expansion of the urban areas, were reported [59]. These results are in line with the future projections suggesting that the majority of Pakistan's anticipated 250 million population will be residing in cities by 2030. Migration and high birth rates are the principal drivers of Pakistan's urban development. Access to better jobs and improved basic needs are a magnet for migrants [35].

The negative correlation of the provision and quality of ecosystem services with unplanned and sporadic urban expansion has been widely reported [7]. Based on this assumption, we speculated that the provision of urban ecosystem service in Multan has decreased in the recent past. To test this assumption, we carried out a survey-based study to inquire the perception of the citizens of Multan about changes in the ecosystem services, and their belief of urban sprawl as an agent of the observed changes in ecosystem services. Evidence suggests that urban sprawl has obvious effects on ecosystem services, such as water quality, microclimate, green spaces, and biodiversity [60]. Previous studies have suggested that urban vegetation is an important indicator of urban ecosystem health and is often seen as a measure of the quality and provision of urban ecosystem services $[60,61]$. Urban green spaces are often strongly correlated to landscape aesthetics and psychological health of the citizens [62]. The results of our spatial analysis indicated a decline in vegetation cover between 1992-2015. Subsequently, the survey results suggested that citizens of Multan strongly believe that air and water quality and green spaces have reduced in the recent past, which corresponds to the assumption that decreasing vegetation cover has obvious effects on the quality and provision of ecosystem services. Similarly, urban infrastructure can influence the urban microclimate by increasing air pollution, creating heat stress, changing wind direction and speed, and altering surface ozone concentration $[60,63]$. Urban sprawl has been reported to increase the urban temperature, a phenomenon known as the Urban Heat Island Effect [60]. Spatial analysis of Multan city indicated a rapid expansion of the footprint in the last couple of decades, and the effects of this expansion were reflected in the survey study where the citizens not only showed strong agreement that the urban temperature of Multan has increased but also agreed that the increasing urban temperature is strongly correlated to the urban sprawl.

Furthermore, we investigated the socioeconomic factors determining the public sensitivity towards the urban ecosystem services and the extent to which people believed those changes are caused by urban sprawl. For the first dependent variable-the public sensitivity or perception about changes in the ecosystem services-the results suggested that the citizens of Multan strongly believe that urban environmental resources and ecosystem services have decreased in the last decade or so (a score of 4.13 on a scale of 1 to 5 ). We found that education and income level were the two significant predictors for this dependent variable. The respondents in Multan city who had a formal education of high school or above were significantly less sensitive to urban environmental change. This result contradicts the general perception that awareness of changes in ecosystem services is strongly correlated with higher formal education. In a global survey where respondents from 119 countries were investigated for the relative effects of socio-demographic characteristics on public climate change awareness, educational attainment was reported as the single strongest predictor of climate change awareness [27]. We believe that our results may have diverged from the general trend because of three reasons. Firstly, most of the survey studies on climate literacy so far have been based on responses from America, Europe, and UK, and only a handful of such studies have investigated the dimensions of public opinion in the developing counties of Asia. The results of the global survey discussed above [27] suggested that education was the strongest predictor for American and European respondents, while in Asian and African countries, education did not have a significant role in shaping public perception of climate change, although the authors concluded that education is a strong overall predictor. Secondly, the least educated citizens in Multan—and most developing countries—are often associated with laborious outdoor jobs. Given that Multan is one of the hottest cities in the world, it is natural for those most exposed to the environment to be more sensitive to the changes in such ecosystem services as precipitation, temperature, atmospheric pollution, and others. Thirdly, our 
results indicated that the respondents with low-income levels are significantly more sensitive to the changes in ecosystem services in Multan city. Again, we found that this predictor had not been reported as a significant predictor of climate change awareness in the developed countries [18]. However, survey studies conducted in many developing countries-especially in tropical agroclimatic zones, such as Bangladesh and Kenya-household income is a very strong predictor of climate literacy $[19,20,64,65]$. This may be attributed to the fact that high-income individuals and families can afford means to combat extreme hot and cold temperatures (through better heating and air conditioning facilities) and often dwell in areas with better green infrastructures. Low-income citizens are often more exposed to the natural environment and, therefore, may show greater sensitivity towards changes in the ecosystem services. For the second dependent variable - the extent to which the respondents believed changes in the ecosystem services are due to urban sprawl - the respondents showed strong agreement (a score of 3.77 on a scale of 1 to 5). We found that the least educated citizens were more convinced of that fact that the observed changes in the ecosystem services are caused by the urban sprawl. We assume that this trend can be attributed to the same argument: The least educated citizens are often associated with outdoor physically laborious jobs, which tends to make them more exposed to the urban environment.

\section{Limitations of the Study}

Although this study provided insights into the spatiotemporal patterns of rapid urban expansion in Multan, it is, however, acknowledged that the spatial analysis was based on land cover maps of $300 \mathrm{~m}$ grain size. Considering the scale of the study area, a finer grain size (i.e., $30 \mathrm{~m}$ ) might reveal more information and a better understanding of the dimensions and amount of urban sprawl $[66,67]$. We also recommend generating future land cover change projection using ensemble modeling approaches, such as the Markov Chain-Multi layer perceptron [33,41]. Future land cover projections might help stakeholders and policymakers to prioritize areas of urban ecosystem conservation. Furthermore, we used six socio-economic variables to explain the variations in the public awareness of changes in the ecosystem services as affected by urban sprawl. In both the regression models, although we found significant predictors among the chosen explanatory variables, the overall variation in the responses explained by the predictors ( $R^{2}$ value) remained low, which means that there may be other underlying explanatory variables. For this, we recommend including more variables in future studies to better explore the drivers underpinning public understanding of urban sprawl and how it affects urban environment. We also acknowledge that the sample size for the survey conducted was, although statistically acceptable, not large enough to draw concrete conclusions. For future studies, we recommend taking a larger sample size (500-1000) for more comprehensive conclusions [31].

\section{Conclusions}

In this study, we assessed the magnitude of city expansion and other land use changes in the recent past. We explored the citizen perception about the quality and provision of ecosystem services and its association with urban sprawl. The respondents of Multan strongly believe that the quality and provision of the ecosystem services in Multan has deteriorated in the last ten years or so, and they hold urban sprawl as one of the main factors responsible for this deterioration. Among the demographic characteristics of the respondents considered in this study, the economically vulnerable and least educated citizens are the most sensitive to environmental changes in the Multan region; however, the regression model suggests that there may be other important demographic and socioeconomic traits which need to be explored in future studies. Future policies of urban environmental management need to focus more on the middle class and lower-middle-class settlements in the city. The government of Pakistan, following its successful completion of the Billion Tree Tsunami is the North Western part of Pakistan (Khyber Pakhtunkhwa) [68], has started an initiative to plant 10 billion trees in the country to mitigate climate change impacts. Cities like Multan, which are not only facing extreme climate change but an additional burden of deteriorating ecosystem services as a consequence of urban sprawl, should be prioritized in the tree-planting campaigns. 
Supplementary Materials: The following are available online at http:/ / www.mdpi.com/2071-1050/11/3/654/s1: Figure S1: Domicile location of respondents interviewed in the study area; Figure S2: Contribution to net change of land use observed in Multan region between 2002-2015(in hectares); Figure S3: Map of the study area showing gain/loss in the land area under the land cover classes, a) urban areas, b) arable land, and c) vegetation cover (tree/shrub) during 2002-2015; Figure S4: Bar Chart showing average responses within each demographic category to the questions on whether the respondents have observed changes in the ecosystem services in the study area; Figure S5. Bar Chart showing average responses within each demographic category to the questions on whether urban sprawl is responsible for changes in ecosystem services in the study area; Table S1: Reclassification of the European Space Agency (ESA) Land cover map for this study. Land cover classes shown in the same color were merged for spatial analysis in this study.

Author Contributions: Conceptualization, S.A.M., A.M., and M.Z.; methodology and survey, S.A.M. and A.M.; statistical analysis, S.A.M. and M.Z.; Writing—original draft preparation, S.A.M., A.M., and M.Z.; Writing-review and editing, M.L. and G.G.

Acknowledgments: The authors acknowledge the services of Ahmed Ansari for conducting the survey study.

Conflicts of Interest: The authors declare no conflict of interest.

Ethical Statement: All survey respondents in this study gave their informed consent for inclusion before they participated in the study.

\section{References}

1. Zhou, D.; Tian, Y.; Jiang, G. Spatio-temporal investigation of the interactive relationship between urbanization and ecosystem services: Case study of the Jingjinji urban agglomeration, China. Ecol. Indic. 2018, 95, 152-164. [CrossRef]

2. Secretariat of the Convention on Biological Diversity Cities and Biodiversity Outlook. 2012. Available online: https: / / www.google.com/url?sa=t\&rct=j\&q=\&esrc=s\&source=web\&cd=2\&ved=2ahUKEwix6vKg4bgAhXYAYgKHeHAAUIQFjABegQIAxAC\&url=https\%3A\%2F\%2Fwww.cbd.int\%2Fauthorities\% 2Fdoc\%2Fcbo-1\%2Fcbd-cbo1-summary-en-f-web.pdf\&usg=AOvVaw2by9T1jQ24Qzugi8LWhzHE (accessed on 6 July 2018).

3. Dobbs, C.; Hernández-Moreno, Á.; Reyes-Paecke, S.; Miranda, M.D. Exploring temporal dynamics of urban ecosystem services in Latin America: The case of Bogota (Colombia) and Santiago (Chile). Ecol. Indic. 2018, 85, 1068-1080. [CrossRef]

4. Ewing, R. Is Los Angeles-Style Sprawl Desirable? J. Am. Plan. Assoc. 1997, 63, 107-126. [CrossRef]

5. Sun, X.; Crittenden, J.C.; Li, F.; Lu, Z.; Dou, X. Urban expansion simulation and the spatio-temporal changes of ecosystem services, a case study in Atlanta Metropolitan area, USA. Sci. Total Environ. 2018, 622-623, 974-987. [CrossRef] [PubMed]

6. Rees, W.E. Ecological footprints and appropriated carrying capacity: What urban economics leaves out. Environ. Urban. 1992, 4, 121-130. [CrossRef]

7. Dupras, J.; Alam, M. Urban Sprawl and Ecosystem Services: A Half Century Perspective in the Montreal Area (Quebec, Canada). J. Environ. Policy Plan. 2015, 17, 180-200. [CrossRef]

8. Sieber, J.; Pons, M. Assessment of urban ecosystem services using ecosystem services reviews and GIS-based tools. Procedia Eng. 2015, 115, 53-60. [CrossRef]

9. Castro, A.J.; Vaughn, C.C.; Julian, J.P.; Llorente, M.G.; Bowman, K.N. Social Perception and Supply of Ecosystem Services-A Watershed Approach for Carbon Related Ecosystem Services. Biodivers. Ecosyst. Link. Struct. Funct. 2015. [CrossRef]

10. Liu, Y.; Yue, W.; Fan, P. Spatial determinants of urban land conversion in large Chinese cities: A case of Hangzhou. Environ. Plan. B Plan. Des. 2011, 38, 706-725. [CrossRef]

11. Journal, I.; Mohapatra, S. An Ecological Analysis of Carrying Capacity and Sustainability. Int. J. Sci. Res. 2015, 2, 335-338.

12. Świąder, M.; Szewrański, S.; Kazak, J.; van Hoof, J.; Lin, D.; Wackernagel, M.; Alves, A. Application of Ecological Footprint Accounting as a Part of an Integrated Assessment of Environmental Carrying Capacity: A Case Study of the Footprint of Food of a Large City. Resources 2018, 7, 52. [CrossRef]

13. Jung, C.; Kim, C.; Kim, S.; Suh, K. Analysis of environmental carrying capacity with emergy perspective of Jeju Island. Sustainability 2018, 10, 1681. [CrossRef]

14. Raudsepp-Hearne, C.; Peterson, G.D.; Bennett, E.M. Ecosystem service bundles for analyzing tradeoffs in diverse landscapes. Proc. Natl. Acad. Sci. USA 2010, 107, 5242-5247. [CrossRef] [PubMed] 
15. Spake, R.; Lasseur, R.; Crouzat, E.; Bullock, J.M.; Lavorel, S.; Parks, K.E.; Schaafsma, M.; Bennett, E.M.; Maes, J.; Mulligan, M.; et al. Unpacking ecosystem service bundles: Towards predictive mapping of synergies and trade-offs between ecosystem services. Glob. Environ. Chang. 2017, 47, 37-50. [CrossRef]

16. Kong, L.; Zheng, H.; Xiao, Y.; Ouyang, Z.; Li, C.; Zhang, J.; Huang, B. Mapping ecosystem service bundles to detect distinct types of multifunctionality within the diverse landscape of the yangtze river basin, China. Sustainability 2018, 10, 857. [CrossRef]

17. Inostroza, L. Measuring urban ecosystem functions through "Technomass"-A novel indicator to assess urban metabolism. Ecol. Indic. 2014, 42, 10-19. [CrossRef]

18. Olander, L.P.; Johnston, R.J.; Tallis, H.; Kagan, J.; Maguire, L.A.; Polasky, S.; Urban, D.; Boyd, J.; Wainger, L.; Palmer, M. Benefit relevant indicators: Ecosystem services measures that link ecological and social outcomes. Ecol. Indic. 2018, 85, 1262-1272. [CrossRef]

19. Beardsley, K.; Thorne, J.H.; Roth, N.E.; Gao, S.; McCoy, M.C. Assessing the influence of rapid urban growth and regional policies on biological resources. Landsc. Urban Plan. 2009, 93, 172-183. [CrossRef]

20. Bengston, D.N.; Fletcher, J.O.; Nelson, K.C. Public policies for managing urban growth and protecting open space: Policy instruments and lessons learned in the United States. Landsc. Urban Plan. 2004, 69, 271-286. [CrossRef]

21. Westerink, J.; Haase, D.; Bauer, A.; Ravetz, J.; Jarrige, F.; Aalbers, C.B.E.M. Dealing with Sustainability Trade-Offs of the Compact City in Peri-Urban Planning Across European City Regions. Eur. Plan. Stud. 2013, 21, 473-497. [CrossRef]

22. Bengston, D.N.; Potts, R.S.; Fan, D.P.; Goetz, E.G. An analysis of the public discourse about urban sprawl in the United States: Monitoring concern about a major threat to forests. For. Policy Econ. 2005, 7, 745-756. [CrossRef]

23. Chen, C.; Wang, Y.; Jia, J. Public perceptions of ecosystem services and preferences for design scenarios of the flooded bank along the Three Gorges Reservoir: Implications for sustainable management of novel ecosystems. Urban For. Urban Green. 2018, 34, 196-204. [CrossRef]

24. Vihervaara, P.; Rönkä, M.; Walls, M. Trends in ecosystem service research: Early steps and current drivers. Ambio 2010, 39, 314-324. [CrossRef] [PubMed]

25. Fagerholm, N.; Käyhkö, N.; Ndumbaro, F.; Khamis, M. Community stakeholders' knowledge in landscape assessments-Mapping indicators for landscape services. Ecol. Indic. 2012, 18, 421-433. [CrossRef]

26. Seppelt, R.; Dormann, C.F.; Eppink, F.V.; Lautenbach, S.; Schmidt, S. A quantitative review of ecosystem service studies: Approaches, shortcomings and the road ahead. J. Appl. Ecol. 2011, 48, 630-636. [CrossRef]

27. Lee, T.M.; Markowitz, E.M.; Howe, P.D.; Ko, C.Y.; Leiserowitz, A.A. Predictors of public climate change awareness and risk perception around the world. Nat. Clim. Chang. 2015, 5, 1014-1020. [CrossRef]

28. Paul, S.; Nagendra, H. Factors Influencing Perceptions and Use of Urban Nature: Surveys of Park Visitors in Delhi. Land 2017, 6, 27. [CrossRef]

29. Pereira, P.; Monkevičius, A.; Siarova, H. Public Perception of Environmental, Social and Economic Impacts of Urban Sprawl in Vilnius. Soc. Stud. 2014, 6, 259-290. [CrossRef]

30. Haller, A. The "sowing of concrete": Peri-urban smallholder perceptions of rural-urban land change in the Central Peruvian Andes. Land Use Policy 2014, 38, 239-247. [CrossRef] [PubMed]

31. Shirazi, S.A.; Kazmi, J.H. Analysis of socio-environmental impacts of the loss of urban trees and vegetation in Lahore, Pakistan: A review of public perception. Ecol. Process. 2016, 5. [CrossRef]

32. Brinkoff, T. The Principal Agglomerations of the World City Population. Available online: http/www. citypopulation.deindex.html (accessed on 3 August 2018).

33. Jafari, M.; Majedi, H.; Monavari, S.M.; Alesheikh, A.A.; Zarkesh, M.K. Dynamic simulation of urban expansion through a CA-markov model case study: Hyrcanian region, Gilan, Iran. Eur. J. Remote Sens. 2016, 49, 513-529. [CrossRef]

34. Weilenmann, B.; Seidl, I.; Schulz, T. The socio-economic determinants of urban sprawl between 1980 and 2010 in Switzerland. Landsc. Urban Plan. 2017, 157, 468-482. [CrossRef]

35. Shaikh, H.; Ijaz, N. International Growth Center. 2017. Available online: https://www.theigc.org/blog/thesix-biggest-challe (accessed on 3 August 2018).

36. Minallah, M.N.; Ghaffar, A.; Rafique, M.; Mohsin, M. Urban Growth and Socio-Economic Development in Gujranwala, Pakistan: A Geographical Analysis. Pak. J. Sci. 2016, 68, 176-183. 
37. Aslam, A.Q.; Ahmad, S.R.; Ahmad, I.; Hussain, Y.; Hussain, M.S. Vulnerability and impact assessment of extreme climatic event: A case study of southern Punjab, Pakistan. Sci. Total Environ. 2017, 580, 468-481. [CrossRef] [PubMed]

38. Umair, S. Sindh, Punjab to Suffer the Most Amid Climate Change Consequences. Available online: https:/ / www.pakistantoday.com.pk/2018/06/28/hyderabad-most-vulnerable-to-suffer-from-climatechange-impacts / (accessed on 9 September 2018).

39. Manzoor, S.A.; Jamil, A.; Ansari, A.N.; Siddique, S.; Javed, J.; Khan, Z.; Youaf, M.; Ijaz, M. How do we perceive climate change? Digging deep in to the public climate change awareness and beliefs in the urban community of Southern Punjab, Pakistan. Russ. J. Agric. Socio-Econ. Sci. 2016, 5, 149-159. [CrossRef]

40. Pakistan Bureau of Statistics 6th Population \& Housing Census-2017. 2018. Available online: http:/ / www. pbscensus.gov.pk/ (accessed on 21 October 2018).

41. Manzoor, S.A.; Griffiths, G.; Iizuka, K.; Lukac, M. Land Cover and Climate Change May Limit Invasiveness of Rhododendron ponticum in Wales. Front. Plant Sci. 2018. [CrossRef]

42. Iizuka, K.; Johnson, B.A.; Onishi, A.; Magcale-Macandog, D.B.; Endo, I.; Bragais, M. Modeling Future Urban Sprawl and Landscape Change in the Laguna de Bay Area, Philippines. Land 2017, 6, 26. [CrossRef]

43. Zizinga, A.; Kangalawe, R.; Ainslie, A.; Tenywa, M.; Majaliwa, J.; Saronga, N.; Amoako, E. Analysis of Farmer's Choices for Climate Change Adaptation Practices in South-Western Uganda, 1980-2009. Climate 2017, 5, 89. [CrossRef]

44. O'Herrin, K.; Day, S.D.; Wiseman, P.E.; Friedel, C.R.; Munsell, J.F. University student perceptions of urban forestry as a career path. Urban For. Urban Green. 2018, 34, 294-304. [CrossRef]

45. Cronbach, L.J.; Meehl, P.E. Construct validity in Psychological test. Psychol. Bull. 1955, 52, 281-302. [CrossRef]

46. Wong, L.P.; Alias, H.; Aghamohammadi, N.; Aghazadeh, S.; Nik Sulaiman, N.M. Urban heat island experience, control measures and health impact: A survey among working community in the city of Kuala Lumpur. Sustain. Cities Soc. 2017, 35, 660-668. [CrossRef]

47. Park, S. A preliminary study on connectivity and perceived values of community green spaces. Sustainability 2017, 9, 692. [CrossRef]

48. Yamane, T. Statistics, An Introductory Analysis, 2nd ed.; Harper and Row: New York, NY, USA, 1967.

49. Solecki, W.; Seto, K.C.; Marcotullio, P.J. It's time for an urbanization science. Environment 2013, 55, 12-16. [CrossRef]

50. Hodson, M.; Marvin, S. Urbanism in the anthropocene: Ecological urbanism or premium ecological enclaves? City 2010, 14, 298-313. [CrossRef]

51. Elmqvist, T.; Fragkias, M.; Goodness, J.; Güneralp, B.; Marcotullio, P.J.; McDonald, R.I.; Parnell, S.; Schewenius, M.; Sendstad, M.; Seto, K.C.; et al. Regional Assessment of Asia; Springer: Berlin, Germany, 2013; ISBN 9789400770881.

52. Adaku, E. Urban Sprawl: A view from developing and developed Countries. Afr. J. Geogr. Reg. Plan. 2014, 1, 193-207.

53. European Environment Agency. Urban Sprawl in Europe-The Ignored Challenge; European Environment Agency: Copenhagen, Denmark, 2006; Volume 10, ISBN 9781405139175.

54. Zhou, D.; Zhang, Z.; Shi, M. Where is the future for a growing metropolis in North China under water resource constraints? Sustain. Sci. 2015, 10, 113-122. [CrossRef]

55. Grimm, N.B.; Faeth, S.H.; Golubiewski, N.E.; Redman, C.L.; Wu, J.; Bai, X.; Briggs, J.M.; Grimm, N.B.; Faeth, S.H.; Golubiewski, N.E.; et al. Global Change and the Ecology of Cities Global Change and the Ecology of Cities. Science 2015, 319, 756-760. [CrossRef] [PubMed]

56. Sung, C.Y.; Yi, Y.J.; Li, M.H. Impervious surface regulation and urban sprawl as its unintended consequence. Land Use Policy 2013, 32, 317-323. [CrossRef]

57. Johnson, M.P. Environmental impacts of urban sprawl: A survey of the literature and proposed research agenda. Environ. Plan. A 2001, 33, 717-735. [CrossRef]

58. SBSTTA. CBD Executive Secretary Ways and means to support ecosystem restoration. CBD SBSTA 15 2011, 17. [CrossRef]

59. Butt, M.J.; Waqas, A.; Iqbal, M.F.; Muhammad, G.; Lodhi, M.A.K. Assessment of Urban Sprawl of Islamabad Metropolitan Area Using Multi-Sensor and Multi-Temporal Satellite Data. Arab. J. Sci. Eng. 2012, 37, 101-114. [CrossRef] 
60. Kopecká, M.; Nagendra, H.; Millington, A. Urban Land Systems: An Ecosystems Perspective. Land 2018, 7, 5. [CrossRef]

61. Haase, D.; Frantzeskaki, N.; Elmqvist, T. Ecosystem services in urban landscapes: Practical applications and governance implications. Ambio 2014, 43, 407-412. [CrossRef] [PubMed]

62. Maraja, R.; Barkmann, J.; Tscharntke, T. Perceptions of cultural ecosystem services from urban green. Ecosyst. Serv. 2016, 17, 33-39. [CrossRef]

63. Lyytimäki, J.; Petersen, L.K.; Normander, B.; Bezák, P. Nature as a nuisance? Ecosystem services and disservices to urban lifestyle. Environ. Sci. 2008, 5, 161-172. [CrossRef]

64. Rahman, S.M.A.; Tasmin, S.; Uddin, M.K.; Islam, M.T.; Sujauddin, M. Climate change awareness among the high school students: Case study from a climate vulnerable country. Int. J. Built Environ. Sustain. 2014, 1, 18-26. [CrossRef]

65. Ajuang, C.O.; Abuom, P.O.; Bosire, E.K.; Dida, G.O.; Anyona, D.N. Determinants of climate change awareness level in upper Nyakach Division, Kisumu County, Kenya. Springerplus 2016, 5. [CrossRef]

66. Gottschalk, T.K.; Aue, B.; Hotes, S.; Ekschmitt, K. Influence of grain size on species-habitat models. Ecol. Model. 2011, 222, 3403-3412. [CrossRef]

67. Manzoor, S.A.; Griffiths, G.; Lukac, M. Species distribution model transferability and model grain size-Finer may not always be better. Sci. Rep. 2018, 1-9. [CrossRef]

68. IUCN Pakistan's Billion Tree Tsunami Restores 350,000 Hectares of Forests and Degraded Land to Surpass Bonn Challenge Commitment. Available online: https:/ / www.iucn.org/news/forests/201708/pakistan\ T1 \textquoterights-billion-tree-tsunami-restores-350000-hectares-forests-and-degraded-land-surpassbonn-challenge-commitment (accessed on 15 November 2018).

(C) 2019 by the authors. Licensee MDPI, Basel, Switzerland. This article is an open access article distributed under the terms and conditions of the Creative Commons Attribution (CC BY) license (http:/ / creativecommons.org/licenses/by/4.0/). 